\title{
The Evolvent of Criteria for Assessment of Innovation Expression in the State Level
}

\author{
Rasa Daugeliene, Simona Juocepyte
}

Kaunas University of Technology

K. Donelaicio st. 73, LT-44029, Kaunas, Lithuania

e-mail: rasa.daugiliene@ktu.lt,simona.juocepyte@ktu.lt

crossref http://dx.doi.org/10.5755/j01.ee.23.2.1540

There are a lot of scientific works were innovation conception is defined. These interpretations usually identify innovation in different environments. It is important to stress that interpretation of innovation in business, industry as well as in public sectors is totally diverse. This complicates the possibility to understand the expression of innovation and more over to assess the level of their penetration. In order to facilitate the understanding of innovation expression in the state level the National Innovation System (NIS) is used as the fundamental instrument. This is a new standpoint highlighted in the article. It is stressed that effective NIS is mostly influenced by various public sectors, private business sectors as well as educational institutions. The business sector is responsible for the inspiration of innovation creation and implementation of appreciable innovative product or service. The public sector is responsible for policy formation and preparation for innovation expansion at the state level.

In the expert works different innovation indexes are used in order to assess the value of innovation expression as well as the effectiveness of NIS functioning in the state level. The main peculiarities of these indexes are highlighted in the article. The article solves the scientific problem which is directly correlated with the situation that there is no unit classification of possible indexes (models) for the assessment of innovation expression in the state level.

According to all arguments mentioned, the authors of this article raise the aim to use analytical (theoretical) as well as empirical methods to systematize the evolvent of criteria for the assessment of innovation expression in the state level as well as to present possible methods and areas of it's application (Lithuania's case). To achieve this aim free tasks were solved in the article: to highlight the main peculiarities of existing indexes for the assessment of innovation expression in the state level; to systematize the groups of quantitative and qualitative criteria as well as to perform empirical research in order to present the evolvent of criteria for the assessment of innovation expression in the state level; to provide the possible methods and areas of application of evolvent of criteria for the assessment of innovation expression in the state level.

The essential result of the research was the classification of possible indexes for the assessment of innovation expression in the state level into two groups. Using the comparison method, all criteria were systematized into 14 quantitative and 11 qualitative criteria. As the consequence of selection of criteria the basic frequently recurrent groups where highlighted (human resource, innovators, economic effect, environment, investment for education, conditions for business provided by public institutions, general infrastructure, scientific output, knowledge creation, investor and creditor conditions, entrepreneurship). The empirical research enabled to specify and adapt for Lithuania the evolvent of criteria for the assessment of innovation expression in the state level. Finally the possible methods and areas of application of evolvent of criteria for the assessment of innovation expression in the state level were presented in the article.

Keywords: innovation expression; National Innovation System (NIS), evolvent of criteria for the assessment of innovation expression.

\section{Introduction}

Rapid technological changes, the information revolution and increasing globalisation have changed the scope of economies. The phenomenon derivative which is called a knowledge economy has born. It overestimated the importance of creation and implementation of innovations in different levels of environment: business, industry and public sector or state. The vast penetration of innovations and the growth of its importance stipulate scientists to identify the different understanding of innovations.

It is important to stress that the most complicated interpretation of innovations is in the state level. The expression of innovations in this level could be assessed by evaluating the scope of National Innovation System (NIS). There are a lot of scientific works (Freeman, 1995; Lundvall, 1985; Metcalfe, 1995; Nelson, 1993; Patel \& Pavitt, 1998; Archibugi et at., 1999; Kriaucioniene \& Jucevicius, 2000; Kalvet, 2001; Nauwelaers, et at. 2003; Ringland, 2003; Johnson, et at. 2003; Paterson et at. 2003; Balzat \& Pyka, 2005; Roos et at. 2005; Herstatt et at. 2008; Krisciunas \& Daugeliene, 2006; Daugeliene, 2008; Haghi et at. 2011) where the attempts of explanation of national innovation system were detailed.

Since the 1980s (see Freeman, 1982; Dosi et al., 1988; Lundvall, 1992; Nelson, 1993), the concept of the NIS has been gaining popularity as a core conceptual framework for analyzing technological change and expression of innovations, 
which is considered to be an indispensable foundation of the long-term economic development of the nation. In the experts researches different innovation indexes are used in order to assess the value of innovation expression as well as the effectiveness of NIS functioning in the state level. However these indexes are oriented to the assessment of expression of innovations in deferent environments and could not be used as the instrument for one country's case (e. g. Lithuania's) (detailed argumentation presented in the first chapter). Existing indexes do not analyze or compare quantitative and qualitative scope of expression of innovation. There is a need to systematize the scope of existing indexes, to extract the possible assessment criteria as well as to highlight the most important criteria for Lithuanian economic environment. Considering the aspects mentioned above the article solves the scientific problem which is directly correlated with the situation that there is no unit classification of possible indexes for the assessment of innovation expression in the state level. Solution of the scientific problem would enable to provide the comprehensive, theoretical instrument for the practical assessment of innovation expression in the state level. Therefore the research problem being solved in this article should be constructed: how to create the evolvent of criteria for the assessment of innovation expression in the state level (Lithuania's case)?

The object of research is an expression of innovation in the state level.

The aim of the article is the use of analytical (theoretical) as well as empirical methods to systematize the evolvent of criteria for the assessment of innovation expression in the state level as well as to present possible methods and areas of its application (Lithuania's case).

To achieve this aim free tasks are to be solved:

- to highlight the main peculiarities of existing indexes for the assessment of innovation expression in the state level;

- to systematize the groups of quantitative and qualitative criteria as well as to perform empirical research in order to verify and adapt the evolvent of criteria for the assessment of innovation expression in Lithuania;

- to provide/propose the possible methods and areas of application of evolvent of criteria for the assessment of innovation expression in the state level.

Theoretical analysis of the scientific works and practical papers in this field was taken as the research method. Empirical research was used in order to specify theoretically constructed evolvent of criteria for the assessment of innovation expression.

Scientific originality and practical significance of the article:

- there was presented a new approach to the possibility for the assessment of innovation expression in the state level;

- in order to systematize the evolvent of assessment of innovation expression the peculiarities of existing indexes for the evaluation of innovation expression were presented;

- empirical research enabled to specify the evolvent of criteria for the assessment of innovation expression as well as to present possible application methods.
Proposed methodology could be widely used by the governmental as well as business representatives.

\section{The Main Peculiarities of Existing Indexes for the Assessment of Innovation Expression in the State Level}

Innovation as phenomenon existed a long time ago, but the origin of the word came from the fifteenth century (Jakubavicius et at. 2003). The experts believe in the role of innovation as increasing the competitiveness of nations, enabling economic growth, driving social changes and building the foundation of a country's future. As subject of economic research, the innovation was named in the fourth decade of twentieth century. Already in the seventh decade of twentieth century innovation started to be interpreted as a distinct research area. It is important to stress that the main preconditions for innovation creation and implementation were highlighted as well. It was the development of science activity, which stipulates the growth of knowledge-based economy.

Various definitions of innovation could be enumerated. At the first half of the twentieth century Austrian economist Joseph Schumpeter was one of the first, who tried to define innovation. J. Schumpeter's (1930) definition presented was: "the introduction of new goods $\langle\ldots\rangle$, new methods of production $\langle\ldots\rangle$, the opening of new markets $\langle\ldots\rangle$, the conquest of new sources of supply $<\ldots>$ and the carrying out of a new organization of any industry." After this conceptual start various scientist tried to define innovation form different perspectives. Here it could be analysed as "the act of introducing of something new" (The American heritage dictionary, 2006), "... the way of transforming the resources of an enterprise through the creativity of people into new resources and wealth" (Schumann, 2008). According to D. Schmittlen (2010) innovation does not relate just to the new product that would come into the marketplace. It can occur in processes and depends on the approaches to the marketplace.

Innovation can be implemented in different levels of country's environment: starting from business, industry and finalising in public sector. As the indicator for the evaluation of effectiveness of creation and implementation of innovation in the state level can be the National Innovation System (NIS). Almost every country has described it more or less.

Free main theoretical standpoints to the NIS could be highlighted. The first, NIS is represented as the structure for explanation of innovation expression in the business field as well as in the state level (Lundvall, 1992; Nelson, 1993; Edquis, 1997). The second, NIS is structured of different institutions, which activities are oriented for the creation and usage of innovation (Rosenberg, 1993). And the third point of view is constructed by C. Edquist (1997), who stresses that innovation system could be identified as all important economic, social, political, organizational and other factors, which influence the level of innovation dissemination and utilization.

In order to assess the spread of innovation in the state level different models/indexes are constructed. They allow identifying the level of innovation expression. The 
procedure of assessment enables to define country's development rate as well as to plan guidelines for a further economic development actions. According to this, the procedure and instruments for innovation expression assessment are defined as a mechanism for the prognosis for further actions considering development of innovation expression in the country.

Often used indexes ${ }^{1}$ for the assessment of innovation expression in the state level are:

- Global Innovation Index,

- Lisbon Index,

- European Innovation Scoreboard,

- Innobarometer.

The analysis of main peculiarities of existing indexes is presented below.

- The Global Innovation Index (GII) is the index measuring the level of innovation in the country. It's produced jointly by The Boston Consulting Group, the National Association of Manufacturers (NAM) and The Manufacturing Institute (MI). This index is described as the largest and most comprehensive global index of innovations. The International Innovation Index is part of large research study that looked at both the business outcomes of innovation and government's ability to encourage and support innovation through the public policy. This index was made from 61 different criteria, which asses a value of innovation at state level.

- The European Innovation Scoreboard (EIS) is the instrument prepared by the European Commission. It was developed to provide the Lisbon Strategy to provide a comparative assessment of the innovation performance of the EU Member States. EIS includes innovation indicators for the EU Member States as well as for Croatia, Turkey, Iceland, Norway, Switzerland, Japan, the US, Australia, Canada and Israel. EIS provides assessment of innovation criteria across the EU and with other countries, which are actively leading innovations. The assessment is based on 28 wide range criteria, which cover structural conditions, knowledge creation and innovative efforts by firms, and outputs in terms of new products, services and intellectual property. Lisbon Index is one of the key programs that focus on innovation indicators, which are based on the Lisbon strategy. Lisbon index has been drawn up at Lisbon strategy, which measures the progress of innovation in the EU. Its aim is to assess the progress of innovation in different region of Europe. Lisbon index asses a value of innovation index through 8 indicators: information society; innovation and $\mathrm{R} \quad \& \quad \mathrm{D}$; market liberalities; telecommunication, transportation; development of finance sector service; business environment; social cohesion; regular growth. It was initiated by the European Commission, which supervises the activities of innovative assessment program. Lisbon index takes data from the World Economic Forum.

\footnotetext{
${ }^{1}$ As it is stressed in the International Dictionary, index is statistical composite that measures changes in the economy or in financial markets, often expressed in percentage changes from a base year or from the previous month. (Vaitkeviciute, 2007). This point of view will be used in the article.
}

- Innobarometer (INN) is focused on the role of innovation in public procurement tenders, the effects of public policies and private initiatives undertaken to boost innovation, and other strategic trends. Every year INN has different aims, tasks. For example the objective of the 2010 Innobarometer survey study the innovation strategies of the European public administration sector in response to changing constraints and opportunities. INN gives descriptive information on the following topics like various types and amount of innovation, composition of teams used in implementation; workforce profiles, skills and training in support of innovative activities and etc.

Analysing the scope of mentioned indexes it could be highlighted that Lisbon Index is based on the quantitative indicators. Global Innovation Index and European Innovation Scoreboard are based partially on qualitative and quantitative indicators. Innobarometer is based only on the qualitative indicators (interview).

Table 1 indicates overlapping criteria of the analysed indexes. There could be highlighted advantages (marked cell of the table) and disadvantages (unmarked cell of the table) of the analysed indexes.

Table 1

\begin{tabular}{|c|c|c|c|c|}
\hline \multicolumn{5}{|c|}{ Overlapping criteria of Lisbon, EIS, GII and INN Indexes } \\
\hline \multirow{2}{*}{ The same group of indicators } & \multicolumn{4}{|c|}{ Innovation Indexes } \\
\hline & Lisbon & EIS & GII & INN \\
\hline Human Resources & $\sqrt{ }$ & $\sqrt{ }$ & & $\sqrt{ }$ \\
\hline Finance and Support & & $\sqrt{ }$ & & $\sqrt{ }$ \\
\hline Linkages \& Entrepreneurship & & $\sqrt{ }$ & & $\sqrt{ }$ \\
\hline Throughputs & & $\sqrt{ }$ & & \\
\hline Innovators & $\sqrt{ }$ & $\sqrt{ }$ & & $\sqrt{ }$ \\
\hline Economic Effects & & $\sqrt{ }$ & & $\sqrt{ }$ \\
\hline Environments & $\sqrt{ }$ & & $\sqrt{ }$ & $\sqrt{ }$ \\
\hline Political Stability & & & $\sqrt{ }$ & $\sqrt{ }$ \\
\hline Regulatory Environment & & & $\sqrt{ }$ & \\
\hline $\begin{array}{l}\text { Conditions for Business provided by } \\
\text { Public Institutions }\end{array}$ & $\sqrt{ }$ & & $\sqrt{ }$ & $\sqrt{ }$ \\
\hline Investment in Education & $\sqrt{ }$ & $\sqrt{ }$ & $\sqrt{ }$ & \\
\hline Quality of Education Institutes & & & $\sqrt{ }$ & \\
\hline Innovation Potential & & & $\sqrt{ }$ & \\
\hline ICT and Uptake of Infrastructure & $\sqrt{ }$ & $\sqrt{ }$ & $\sqrt{ }$ & $\sqrt{ }$ \\
\hline ICT Infrastructure & $\sqrt{ }$ & $\sqrt{ }$ & $\sqrt{ }$ & $\sqrt{ }$ \\
\hline General Infrastructure & & & $\sqrt{ }$ & \\
\hline Uptake and Usage of Infrastructure & & & $\sqrt{ }$ & \\
\hline Market Sophistication & & & $\sqrt{ }$ & \\
\hline Investor and Creditor Conditions & & & $\sqrt{ }$ & \\
\hline Access to Private Credit & $\sqrt{ }$ & $\sqrt{ }$ & & $\sqrt{ }$ \\
\hline Business Sophistication & & & $\sqrt{ }$ & \\
\hline Innovation Environment in Firms & & & $\sqrt{ }$ & \\
\hline Innovation Ecosystem & $\sqrt{ }$ & & $\sqrt{ }$ & $\sqrt{ }$ \\
\hline $\begin{array}{l}\text { Openness to Foreign and Domestic } \\
\text { Competition }\end{array}$ & $\sqrt{ }$ & $\sqrt{ }$ & $\sqrt{ }$ & $\sqrt{ }$ \\
\hline Scientific Outputs & & $\sqrt{ }$ & $\sqrt{ }$ & \\
\hline Knowledge Creation & & $\sqrt{ }$ & $\sqrt{ }$ & \\
\hline Knowledge Application & & & $\sqrt{ }$ & \\
\hline Exports and Employment & & $\sqrt{ }$ & $\sqrt{ }$ & \\
\hline Creative outputs \& Well-being & $\sqrt{ }$ & & $\sqrt{ }$ & \\
\hline Creative Outputs & $\sqrt{ }$ & $\sqrt{ }$ & & $\sqrt{ }$ \\
\hline Benefits to Social Welfare & & $\sqrt{ }$ & & $\sqrt{ }$ \\
\hline
\end{tabular}


It could be explained that e.g. human resource as the possible indicators for evaluation of innovation expression is presented by Lisbon, EIS, and INN Indexes. The conclusion could be that this group of criteria is very representative for assessment of innovation expression. According to this the criteria of these indexes will be used in constructing theoretical evolvent of criteria for the assessment of innovation expression in the state level.

\section{Theoretically Constructed Structure of the Evolvent of Criteria for the Assessment of Innovation Expression}

According to all indexes of innovation (Lisbon, GII, EIS, INN), which explore different or the same innovation criteria in the state level, we could construct whole set of indicators (Table 1). They could be used in order to asses the value of innovation in the state level. As the Table 1 shows, recurrent groups of Index criteria are: human resource, innovators, economic effects, environment, investment for education, conditions for business provided by public institutions, general infrastructure, scientific output, knowledge creation, investor and creditor conditions, entrepreneurship. These groups represent the situation and penetration of innovation creation, dissemination, acquisition as well as usage. Considering mentioned above the theoretical evolvent of criteria for the assessment of innovation expression is constructed (see Fig. 1). There was made hypothetical precondition that all analysed indexes aim to evaluate innovation expression rate in the state level. This kind of assessment could be described as overlapping comprehensive method of assessment of innovation expression in the state level.

Theoretically constructed evolvent of criteria for the assessment of innovation expression in the state level consists of two main criteria groups: quantitative criteria group and qualitative criteria group. They where systematized in analysing existing indexes (see Fig. 1). The overlapping quantitative and qualitative criteria were selected for the basic assessment (more experimental) of innovation expression. Considering that the conclusion could be made that the selection of criteria groups depends on what is the purpose of the assessment as well as what kind of conclusion is expected. If there is a need for more sophisticated assessment the $1^{\text {st }}$ group of criteria should be used. Usually the quantitative criteria allow to identify and to compare situations and positions of different states' or regions. The qualitative criteria allow identifying not only the static situation considering innovation expression but enforce to forecast reasons as well as preconditions for the innovation expression in the state.

For more concentrated research - the $2^{\text {nd }}$ group overlapping criteria should be used. These criteria, as being systematized from the $1^{\text {st }}$ group criteria, allow to get comprehensive quantitative as well as qualitative conclusions considering the situation of innovation expression in country. These indicators reflect the whole group of different criteria, such as - for calculating gross domestic product (GDP); expenditure-new information technology; inflation; foreign direct investment; the country's foreign investment; unemployment rate; export and import levels; situation of small and medium business; services; patented products; education level of population; investment in higher education; how quickly the public sector serving business; cooperation of research, academic institutions and business; the costs of infrastructure improvements; development and implementation of innovation. The correlations between criteria could be highlighted as well.

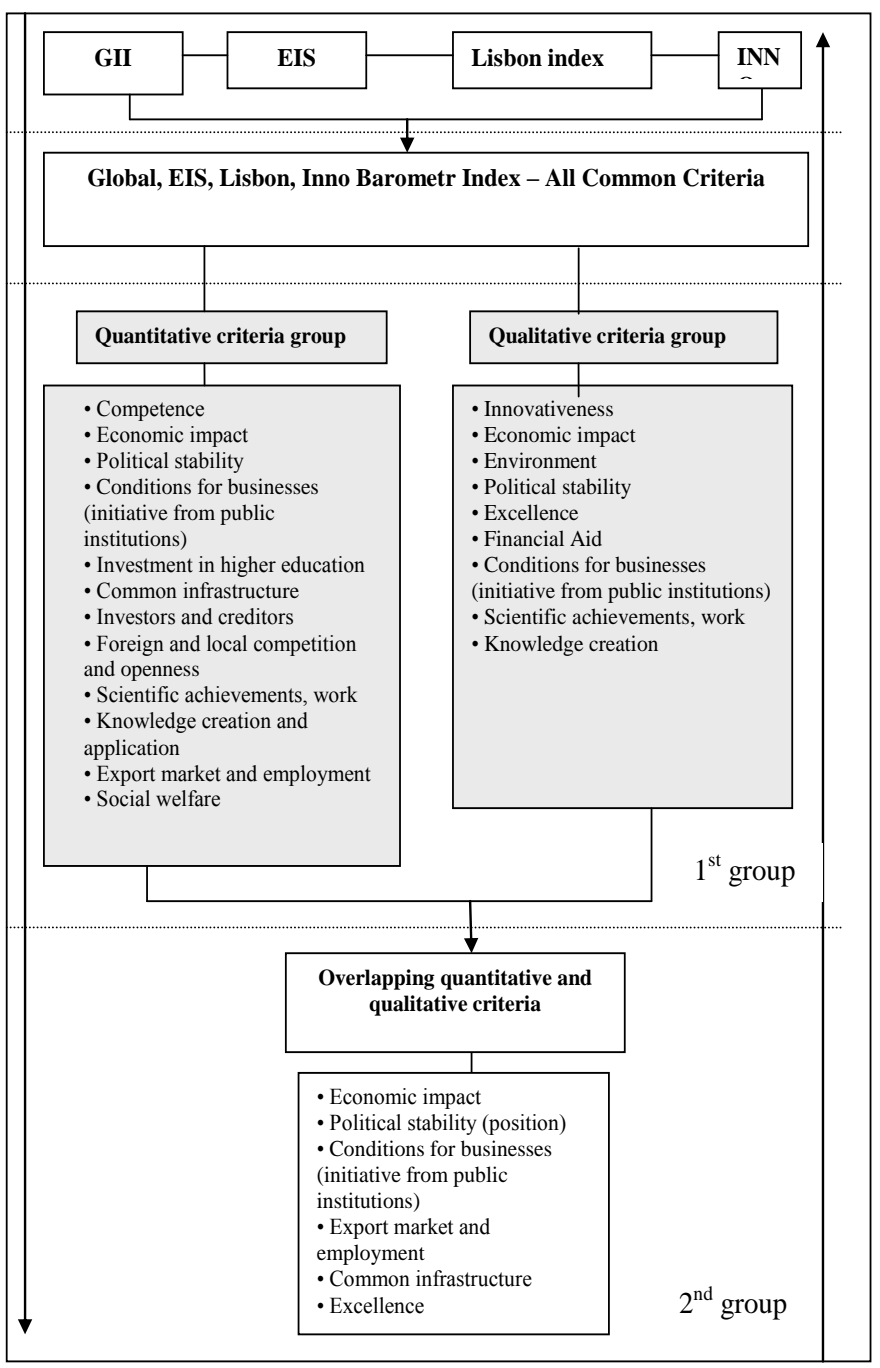

Figure 1. Theoretical Evolvent of Criteria for the Assessment of Innovation Expression in the State Level

\section{The Empirical Research in Order to Specify the Evolvent of Criteria for the Assessment of Innovation Expression}

The aim of the empirical research is to verify systematized evolvent of criteria for the assessment of innovation expression in the state level.

The object of research - the criteria of innovation expression in Lithuania. The respondents of semistructured interview were seven experts, who represented different institutions which were working and researching innovation in the state level. After the determination of empirical research aim the structured substantiation of research instrumentation was constructed (see Table 2). Instrumentation was used to get a first source of information for research analyse. 
Table 2 extends the information-gathering capabilities, accuracy,

Substantiation of Interview Questions (created by author's)

\begin{tabular}{|l|l|l|}
\hline No & $\begin{array}{l}\text { Studies of research for } \\
\text { assessment of innovation } \\
\text { expression in Lithuania }\end{array}$ & \multicolumn{1}{c|}{ Questions } \\
\hline 1 & $\begin{array}{l}\text { Most popular index to evolve } \\
\text { the criteria for assessment of } \\
\text { innovation expression in the } \\
\text { Lithuania. }\end{array}$ & $\begin{array}{l}\text { What is the most popular index for } \\
\text { assessment of innovation expression } \\
\text { in Lithuania? Which method or } \\
\text { index is most effective? Why? }\end{array}$ \\
\hline 2 & $\begin{array}{l}\text { Need for assessment of } \\
\text { innovation expression in } \\
\text { Lithuania. Obvious problems } \\
\text { considering the application of } \\
\text { models or indexes. }\end{array}$ & $\begin{array}{l}\text { For what purpose it is necessary to } \\
\text { assess the innovation expression } \\
\text { level in Lithuania? Why? }\end{array}$ \\
\hline 3 & $\begin{array}{l}\text { The most sensitive criteria for } \\
\text { assessment of innovation } \\
\text { expression in Lithuania. }\end{array}$ & $\begin{array}{l}\text { What kind of quantitative and } \\
\text { qualitative criteria for assessment of } \\
\text { innovation expression in Lithuania } \\
\text { do you know? Which of them are } \\
\text { the most actual? }\end{array}$ \\
\hline 4 & $\begin{array}{l}\text { The evaluation of theoretical } \\
\text { evolvent of criteria for } \\
\text { assessment of innovation } \\
\text { expression. }\end{array}$ & $\begin{array}{l}\text { What do you think about } \\
\text { theoretically selected criteria for } \\
\text { assessment of innovation } \\
\text { expression in Lithuania? Why do } \\
\text { you think so? }\end{array}$ \\
\hline 5 & $\begin{array}{l}\text { Recommendations for the } \\
\text { evolvent of criteria for } \\
\text { assessment of innovation } \\
\text { expression in Lithuania }\end{array}$ & $\begin{array}{l}\text { What criteria could be withdrawn } \\
\text { or enclosed to the suggested } \\
\text { evolvent? }\end{array}$ \\
\hline
\end{tabular}

Research method. The research method was chosen - semistructured interview. This method was chosen because it and allows analyzing the research problem (Guscinskiene, 2004). During interviews there were intensive communications process between informants and researcher. At this research type, researchers interweaved informants according to the prepared plan of questions. Despite prepared questions, researchers asked interweavers' additional questions. The interview with informant agreement was recorded.

Research respondents. Qualitative research was made according to expert's recommendations. The rule was created that "expert" can be any person, who has a prolonged or intense experience through practice and education in a particular field. In specific fields, the definition of expert is well established by consensus and therefore it is not necessary for an individual to have a professional or academic qualification for them to be accepted as an expert. According to that, for this research the experts were taken from different Lithuanian national innovation system components: the business sector, public sector, higher education, non-governmental organization and business associations. All the audience identified important roles in the national innovation system. Based on research ethics, research informants or exact names of companies' weren't revealed.

The results of empirical research enabled to revise the scope of quantitative and qualitative (see Figure 2).

\begin{tabular}{|c|c|c|c|c|c|}
\hline \multicolumn{3}{|c|}{ In put } & \multicolumn{3}{|c|}{ Out put } \\
\hline $\begin{array}{c}\text { Favor of economy } \\
\text { to the innovative } \\
\text { activity }\end{array}$ & $\begin{array}{c}\text { Favor of legal } \\
\text { system for } \\
\text { innovative activity }\end{array}$ & $\begin{array}{c}\text { Inf rastructure of } \\
\text { innovation }\end{array}$ & Human resource & $\begin{array}{c}\text { Assumptions for } \\
\text { entrepreneurship }\end{array}$ & $\begin{array}{c}\text { Business and education } \\
\text { cooperation }\end{array}$ \\
\hline $\begin{array}{l}\text { Taxes, preferences } \\
\text { for patents }\end{array}$ & $\begin{array}{l}\text { The legal system } \\
\text { adapted for } \\
\text { innovative activity }\end{array}$ & R\&D development & $\begin{array}{r}\text { Population with } \\
\text { higher education }\end{array}$ & $\begin{array}{l}\text { Venture capital (percent of } \\
\text { GDP) }\end{array}$ & $\begin{array}{l}\text { Universities and research } \\
\text { centers } \\
\text { in cooperation with business }\end{array}$ \\
\hline $\begin{array}{l}\text { Special taxes for } \\
\text { innovative } \\
\text { companies }\end{array}$ & $\begin{array}{c}\text { Effectiveness of } \\
\text { government policies }\end{array}$ & $\begin{array}{c}\text { Effectiveness of } \\
\text { activities of } \\
\text { innovation centers, } \\
\text { science parks and } \\
\text { business }\end{array}$ & $\begin{array}{l}\text { Higher education } \\
\text { quality }\end{array}$ & $\begin{array}{l}\text { Education and training } \\
\text { about entrepreneurship }\end{array}$ & $\begin{array}{c}\text { Numbers of patents for } \\
\text { innovative products, services. }\end{array}$ \\
\hline Export & $\begin{array}{c}\text { Political support for } \\
\text { innovations }\end{array}$ & $\begin{array}{l}\text { Quality of activities of } \\
\text { research centers }\end{array}$ & $\begin{array}{l}\text { Cost of companies } \\
\text { in-service training }\end{array}$ & Spin-off activities & $\begin{array}{c}\text { Innovative business } \\
\text { properties }\end{array}$ \\
\hline $\begin{array}{c}\text { Inflation, } \\
\text { unemployment level }\end{array}$ & $\begin{array}{c}\text { Time of } \\
\text { corporate liquidity }\end{array}$ & $\begin{array}{l}\text { The expenditures for } \\
\text { ICT }\end{array}$ & $\begin{array}{c}\text { Costs of higher } \\
\text { education (of GDP) }\end{array}$ & Number of spin-offs & $\begin{array}{l}\text { Implementation of innovative } \\
\text { activities and ROI }\end{array}$ \\
\hline GDP & - & $\begin{array}{l}\text { Environment of } \\
\text { infrastructure }\end{array}$ & Social welfare & - & - \\
\hline
\end{tabular}

Figure 2. Specified Quantitative and Qualitative Indicators of Evolvent of Criteria for the Assessment of Innovation Expression in Lithuania

\section{Possible Methods and Areas of Application of the Specified Evolvent of Criteria for the Assessment of Innovation Expression in the State Level}

The evolvent of criteria is suggested to be used for the governments, state departments, municipalities, international organizations in order to measure the friendless of environment for the creation and application of innovation in Lithuania. This research could enable to highlight concerned problems and propose suitable solutions for their elimination.

It is important to stress that innovation expression assessment strongly depends on the assessment purpose.
This idea is presented in Figure 3. Considering the assessment purpose the researcher should apply analytical or system approach and consequently to perform concentrated or expanded assessment (it depends on the amount of criteria). The assessment methods, processing research data as well as specificity of conclusions depend on the assessment purpose either.

In application of the evolvent of criteria of innovation expression assessment the hypothetic deduction paradigm (Smith, Glass, 1987) is proposed to be used as a reference in research planning scheme (the algorithm sequence) (see Figure 3). To implement this paradigm the innovation expression assessment algorithm has been worked out in which two possible assessment types are pointed out: 
declarative and analytical (predictive), also, further sequence of assessment which depends on them.

There is a proposal to substantiate the innovation expression assessment by systemic methodological approach which appeared in the 20th century, when assessment is carried out referring to the well-known assessment models considering the reality pragmatically and interpreting it in terms of positivism and hermeneutics. The systemic approach is in favour of integration of qualitative and quantitative researches and suggests that the relationship of the applied method is determined by the aim and object of the research. The evolvent of criteria for the assessment of innovation expression should be applied by means of statistical models, indexes which apply qualitative research methods or both of them. The second method let to find out quantities and qualitative research together.

Accordingly to taken assessment purpose, it will take the process of research data and analyses. Theoretical processing, qualitative analysis, quantitative analysis or quantitative together - all of them will give specificity of conclusions.

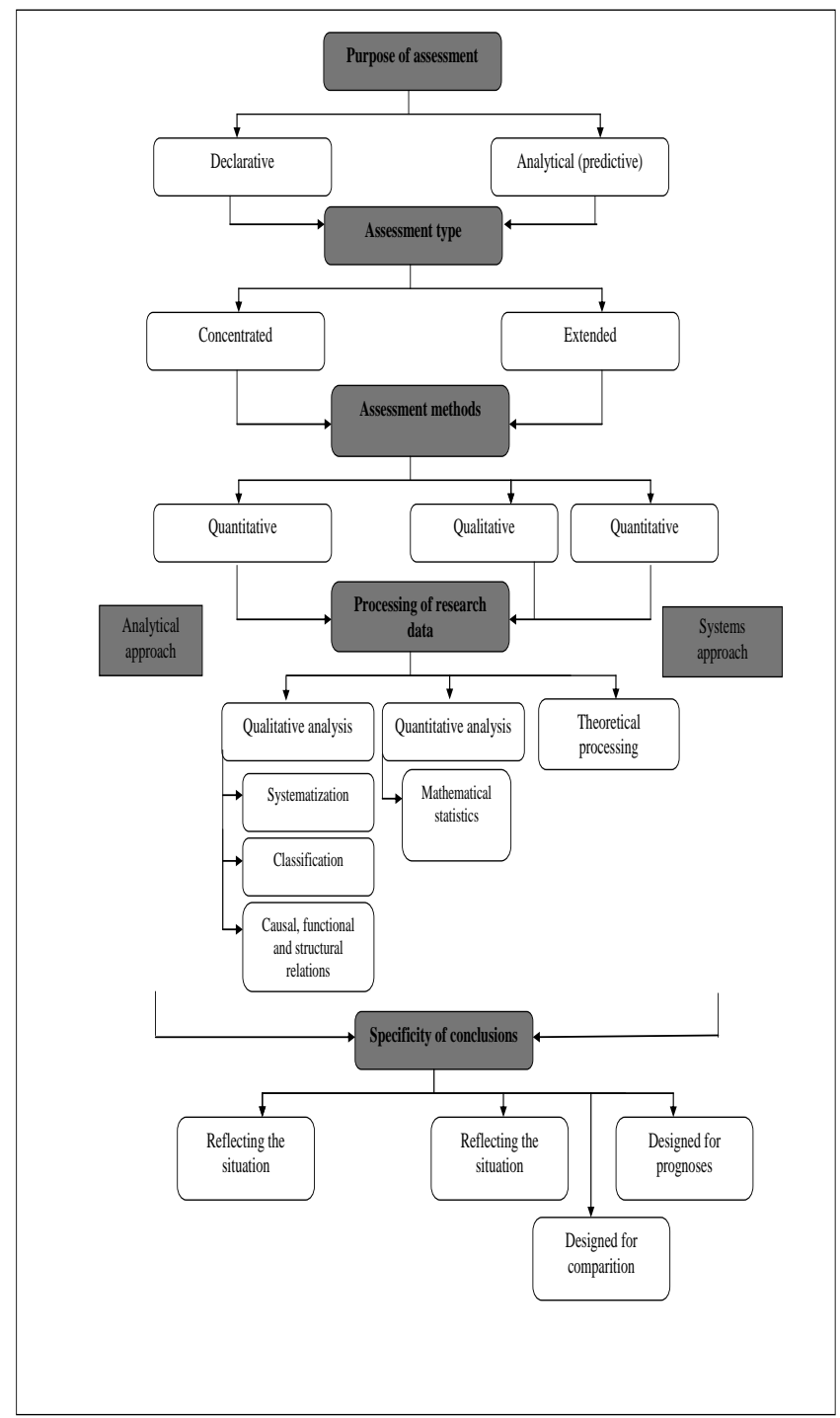

Figure 3. The Algorithm for the Application of Evolvent of Criteria for the Assessment of Innovation Expression in State Level (Daugeliene, 2005)

\section{Conclusions}

- As the analysis confirmed, innovation expression as well as effectiveness of national innovation systems usually are assessed using existing models as well as indexes. Consequently the main indexes for the assessment of innovation expression in the state level (Global Innovation Index (GII), Lisbon Index, European Innovation Scoreboard, Inno Barometer) were highlighted and systematized. The analysis of scientific works as well as practical surveys enabled to make a conclusion that evolvent of criteria for the assessment of innovation expression in the state level still missing. Therefore there were identified the elements of existing indexes for the evaluation of innovation expression and the conceptual scope of those presented. All analysed innovation indexes indicate overlapping group of criteria. They are human resources, economic effects, common infrastructure, political stability and entrepreneurship. It is important to stress that these groups of criteria are representative for assessment of innovation expression in the state level. Taking into account the scope of analysed indexes theoretical evolvent of criteria for the assessment of innovation expression in the state level was constructed.

- It was observed that all criteria of existing (or used in practise) indexes can be classified into two groups quantitative and qualitative criteria group. The quantitative criteria include competence, economic impact, political stability, creation of conditions for businesses (initiative of state public institutions, agencies), investment in higher education, common infrastructure and etc. The group based on qualitative criteria includes innovativeness, economic impact, environment, political stability, excellence, financial aid, common infrastructure, scientific achievements, knowledge creation and others. It is important to stress that some of criteria are overlapping because there is possibility to evaluate, e. g. knowledge creation quantitatively as well as qualitatively. The overlapping group of criteria is: human resource, innovators, economic effect, environment, and investment for education, conditions for business provided by public institutions, general infrastructure, scientific output, knowledge creation, investor and creditor conditions, entrepreneurship. These criteria reflect the whole group of different indicators, such as: Gross domestic product (GDP), expenditure-new information technology, inflation rate, foreign direct investment, unemployment rate, export and import, number of patents, education level of population, investment in higher education, how quickly the public sector serving businesses, research institutions, academic and business cooperation, development and implementation of innovation.

- The evolvent of criteria for the assessment of innovation expression in the state level was newly constructed. The empirical research enabled to specify theoretical evolvent of criteria for the assessment of innovation expression in Lithuania. The results of empirical research showed that:

- innovation expression in Lithuania usually is interpreted as number of created patents and level of export. This is very narrow viewpoint; 
- the main problems of application of existing innovation expression assessment indexes in Lithuania are: too fast change of methodology of indexes; indexes constant just the current static situation; the correlation of research results is not studied; the results of studies are not used practically properly;

- there was a recommendation to modify highlighted theoretical model. Therefore 6 sensitive criteria groups for Lithuania case were systematized. These were economic favour for the innovative activity, legal basis favour for innovation creation, structure of innovations, human recourses, preconditions for entrepreneurship, science and business cooperation;

- the most important criteria for the innovation expression in Lithuania is education and training of entrepreneurship.

- The possible areas of application of the proposed evolvent depends on the purpose, type and methods of innovation expression assessment in the state level, quantitative, qualitative or mixed criteria could be used. The scope of criteria depends on the specificity of approach (analytical or systemic). Presented model could be used in Lithuania for the assessment of innovation expression. It is recommended to survey the conditions and consequences of innovation creation and implementation periodically in order to identify the barriers for innovation expression quickly;

- Considering the results of empirical research there could be made the assumption on the suggested evolvent of criteria could be used in practice. Nevertheless hypothetical limitations of the proposed evolvent could be provided. The first one, the evolvent of criteria is applicable for the research in the macroeconomic level (sector of economy but not in the micro-enterprise level). Second, usually the results of assessment of innovation expression in the state level (even by using unique, comprehensive instrument) are not used practically properly. The third, the entrepreneurs of Lithuania do not recognize the importance of such researches' (it is suppose to state that such opinion could be based on not confidence of economic situation). The possible future research developments should be oriented on practical examination of suggested evolvent of criteria for the assessment of innovation expression in Lithuania.

\section{References}

Archibugi, D., Howells, J., \& Michie, J. (1999) Innovation policy in a global economy. Cambridge University press. ISBN 0521633273. p. 278 http://dx.doi.org/10.1017/CBO9780511599088

Bruce, R. J. (2000). Integruotos verslo studijos.Vilnius, The Baltic Press.

Carayannis, E. G., \& Gonzalez, E. (2003). Creativity and Innnovation = Competitiveness? When, How and Why? In Shavinina, L. V. (2003). The international handbook on Innovation.

Druker, P. F. (1992). Managing for the Future, Butterworth-Heinemann, Oxford.

Edquist, C. (1997). Systems of Innovation Approaches. Their Emergence and Charakteristics. In Edquist C. (Ed). Systems of Innovation: Technologies. Institutions and Organizations: London: Pinter Cassel Academic

Edquist, C. (2005). Systems of innovation: Perspectives and challenges, in Fagerberg, J., Mowery D. and Nelson, R. (eds.), Handbook of Innovation, Oxford University Press.

Europos Komisija (2009). (Pramone ir verlsas). European innovation scoarbourd 2009. Prieiga per internetą: http://ec.europa.eu /enterprise/e_i/subscription_en.htm

Europos Komisija. Zalioji inovaciju knyga (angl. k. Green Paper on Innovation). (1995). Prieiga intenerte adresu: http://cordis.europa.eu/fetch?CALLER=PROGLINK_EN\&ACTION=D\&DOC=1\&CAT=PROG\&QUERY=012648 bb30ad:8970:046b8b61\&RCN=462

Fagerberg, J., Mowery, C., \& Nelson, R. (2005). The Oxford Handbook of Innovation. Oxford: Oxford University Press.

Freeman C. (1987). Technology and Economic Performance: Lessons from Japan. London: Pinter Publishers.

Global innovation index (2009). Confereration of Indian industry. Prieiga per interneta: http://www.insead.edu/facultyres earch/centres/elab/documents/GIIFinal0809.pdf

Global innovation index updated analyse and report (2009-2010). George Skaria/Confereration of Indian industry. Prieiga per interneta: http://www.globalinnovationindex.org

Daugeliene, R. (2008). The streamline of research and experimental development's infrastructure in Lithuanian national innovation system. Inzinerine Ekonomika-Engineering Economics(2), 61-69.

Daugeliene, R. (2005). Ziniu raiskos vertinimo ziniomis gristoje ekonomikoje instrumentarijaus teorinis modeliavimas. Disertacija, ISM Tarptautine aukstoji vadybos mokykla. 139

Haghi, S., Sabahi, A., \& Salnazaryan, A. (2011). Institutions and functions of national innovation system in Norway and Iran. African Journal of Business Management, 5(24), 10108-10116. Prieiga per internetą: http://www.academicjou rnals.org/ajbm/PDF/pdf2011/14Oct/Haghi\%20et\%20al.pdf

Heshmati, A., \& Tausch, A. (2007). Roadmap to Bangalore?: globalization, the EU's Lisbon process and the structures of global inequality. New York: Nova Science Publishers 
Innobaromater summary (2009). Directorate General Enterprise and Industry ir Directorate General Communication. Prieiga per internetą: http://ec.europa.eu/public_opinion/flash/fl_267_sum_en.pdf

Jakubavicius, A., Strazdas, R., Gecas, K.( 2003). Inovacijos: procesai, valdymo modeliai, galimybes. Vilnius: Lietuvos inovaciju centras.

Joy Li (2010) Innovation the key to future success. Prieiga per internetą: http://www.chinadaily.com.cn/hkedition/2010 11/03/content_11493122.htm

Jucevicius, G., Kriaucioniene, M., Ragauskas, A. (2008). Inovatika ir globali ziniu ekonomika. Kaunas. Spaustuve „Non Porelis“.

Lundvall, B. A. (1992). User-Producer Realationships, National Systems of Innovation and Internalisation. In Lundvall, B.A. (Ed.), National Systems of Innovation. Towards a Theory of Innovation and interactive Learning. London: Piter Publishers.

Matler, A. (2009). Lisbon Council e-brief: Innovating Indicators for EU 2020. Prieiga per internetą: http://www.lisbon council.net/publication/publication/55-innovatingindictors.html

Melnikas, B., Lubanavicius, A., Strazdas, R. (2000). Inovacijos - verslas, vadyba, konsultavimas. Vilnius: Lietuvos inovaciju centras.

Melnikas, B., Lubanavicius, A., Strazdas, R. (2000). Inovaciju vadyba.Vilnius. „Technika“.

National Systems of Innovation documentas DSTI/STP/TIP(97)2, DST, OECD, Paris (1997). Prieiga per internetą: http://www.adiat.org/documento/33.pdf

Nelson, R. R., Rosenberg, N. (1993). Technical Innovation and National Systems. In Nelson, R. R. (Ed), National Systems of Innovation: a Comparative Study. Oxfors: Oxford University Press

Norgren, L., \& Hauknes, J. (1999). Economic rationales of government involvement in innovation and the supply of innovation-related services // STEP Report series. The STEP Group, Studies in technology, innovation and economic policy.

North, D. (1990). Institutions, Institutional Change and Economic Performance, Cambridge: Cambridge University Press.

Sakalas, A., Vanagas, P., Martinkus, B., Nevarauskas, B., Prokupčiukas, B., Venskus, R., Virvilaite, R., Ivaskiene, A. (2000). Pramones imoniu vadyba. Kaunas: Technologija.

Schumpeter, J. (1934). The theory of economic development, Cambridge, MA: Harvard University Press.

Strazdas, R., Jakubavicius, A, Gecas, K. (2003). Inovacijos: finansavimas, rizikos kapitalas. Vilnius. Lietuvos inovaciju centras. Prieiga intenerte adresu: http://www.inovacijos.lt/inopagalba/cms/65lt.pdf

The Global Innovation Index and Report (2009) - newcomer among innovation indicators. Deutshce bank report. Prieiga per internetą: http://www.dbresearch.com/PROD/DBR_INTERNET_EN-PROD/PROD0000000000236886.pdf

Unger, B., \& Zagler, M., (2003). Institutional and organizational determinants of product innovations. Innovation: The European Journal of Social Science, 16(3).

Verspagen, B. (2006). Innovation and Economic Growth, in Fagerberg J, Mowery, D. \& Nelson, R (eds). The Oxford Handbook of Innovation. Oxford: Oxford University Press. http://dx.doi.org/10.1093/oxfordhb/9780199286805.003.0018

Rasa Daugèlienè, Simona Juočepytė

Kriterijų išklotinė inovacijų raiškai nustatyti valstybės lygmeniu

Santrauka

Valstybei, norinčiai efektyviai skatinti inovacijų raišką šalyje, būtinas nuoseklus inovacijų raiškos stebejjimas, šio proceso koordinavimas ir tikslingas skatinimas. Valstybè, nustačiusi jautriausius kriterijus, atskleidžiančius inovaciju raišką šalyje, gali ištirti inovacijų raiškos priežastis bei spragas. Inovacijų samprata, jų turinys bei raiška įvairių aplinkų nagrinėjama daugelyje mokslinių darbų (Freeman, 1995; Lundvall, 1985; Metcalfe, 1995; Nelson, 1993; Patel, Pavitt, 1998; Kriaučioniené, Jucevičius, 2000; Kalvet, 2001; Nauwelaers, Veugelers, Looy, 2003; Ringland, 2003; Johnson, Edquist, Lundavll, 2003; Paterson, Adam, Mullin, 2003; Balzat, Pyka, 2005; Roos, Ferstrom, Gupta, 2005; Herstatt, Tiwari, Buse, 2008; Kriščiūnas, Daugèlienė, 2006; Daugèlienė, 2008). Teigiama, kad inovacijos - nuolat kintantis procesas, kurio raiškos efektyvumas priklauso nuo daugelio veiksnių, o ypač nuo valstybėje vykdomos politikos bei aplinkos, palankios veiklai ir skirtingų subjektų (įmonių, valdžios institucijų, finansinę ir informacinę paramą teikiančių organizacijų, švietimo ir mokslo institucijų) komunikavimo. Efektyvus minètų subjektų bendradarbiavimas gali būti užtikrintas pasitelkiant inovaciju sistemas.

Nacionalinių inovacijų sistemų (NIS) pagrindinė funkcija yra skatinti inovacijų raišką valstybèje. Už inovacijų kūrimą bei diegimą yra atsakingos valstybinès institucijos, privatus sektorius bei švietimo ir tyrimo institucijos. Verslo sektorius atsakingas už inovatyvaus produkto ar paslaugos kūrimą ir diegimą šalyje. Viešojo sektoriaus atsakomybès apsiriboja politikos formavimu bei įstatyminės bazès paruošimu.

Valstybeje, inovacijų raiškai stebėti, naudojami skirtingi indeksai bei modeliai. Inovacijų indeksai atskleidžia inovacijų raišką kiekybiniais rodikliais (tokiais, kaip moksliniai tyrimai, rinkos liberalumas, socialinè sanglauda) (Lisabonos indeksas) ir kokybiniais rodikliais (vykdomi nestruktūruoti interviu apie verslo investicijas kuriant, diegiant ir plètojant inovacijas ) (Inovacijų Barometras). Taip pat pastebėta, kad egzistuoja inovacijų raiškos indeksai, kurie inovacijų skverbti nagrinėja valstybès lygmeniu (Lisabonos indeksas), kiti - igalina palyginti pasaulio regionus (Globalus inovacijų indeksas), tretieji nagrinėja atskirų valstybės sektorių (pvz.: verslo) investicijas diegiant inovacijas (Inovacijų Barometras).

Nei moksliniuose, nei praktiniuose ekspertų darbuose neteko rasti visuminès inovacijų indeksu klasifikacijos, kuri igalintu tyrejją pasirinkti tinkamiausią metodą inovacijų raiškai šalyje ar sektoriuje nustatyti. Daugelyje egzistuojančių indeksų neanalizuojami tyrimų panaudojimo rezultatai. Dėl to tikslinga yra sudaryti kriterijų išklotinę inovacijų raiškai nustatyti valstybẻs lygmeniu. 
Atsižvelgiant $\mathfrak{i}$ išdèstytas mintis darbo autoriai iškèlè tikslą - panaudojant sisteminius (teorinius) bei empirinius metodus, susisteminti kriteriju išklotinę inovaciju raiškai šalyje nustatyti (Lietuvos atvejis). Tikslui pasiekti straipsnyje iškelti tokie uždaviniai: išryškinti pagrindinius egzistuojančius indeksus, kurie naudojami siekiant nustatyti inovacijų raiškos valstybèje ypatumus; susisteminti kiekybinių ir kokybinių kriterijų grupes bei atlikti empirini tyrimą, kuris leistų patikrinti bei adaptuoti Lietuvai kriterijų išklotinę inovacijų raiškai nustatyti valstybės lygmeniu; pasiūlyti galimus kriteriju išklotinès inovaciju raiškai nustatyti taikymo metodus bei sritis.

Analizei buvo pasirinkti pagrindiniai pasaulyje naudojami inovacijas nustatantys Lisabonos, Suminis inovatyvumo, Inovaciju Barometro bei Globalaus inovaciju indeksai. Išgrynintos pagrindiniu indeksų tyrimo metodikos, kompleksiniai rodikliai, kurie dažniausiai pasikartoja ir yra svarbūs nustatant inovacijų kūrimą ir diegimą, taip pat inovacijų raišką šalies lygmeniu.

Atrinktieji rodikliai buvo suskirstyti ị 14 kiekybinių ir 11 kokybinių rodiklių. Iš jų išgrynintos ir nagrinèjimui parinktos 7 kiekybiniu ir kokybiniu rodikliu grupès Tai - ekonomikos poveikis, politiné padètis, viešujų istaigu itaka, sąlygos verslui, eksportas - importas, rinkos užimtumas, bendroji infrastruktūra, kompetencijos.

Šias rodikliu grupes atspindi skirtingu kriteriju visuma: apskaičiuojama Bendrojo vidaus produkto (BVP) dalis naujoms informacinėms technologijoms, infliacijos lygis, tiesioginès užsienio investicijos šalyje, šalies investicijos užsienyje, nedarbo lygis, eksporto ir importo lygis, smulkaus ir vidutinio verslo situacija, užpatentuotų paslaugų ir produktų skaičius, aukštujų mokyklų skaičius, turinčiujų aukštaji išsilavinimą skaičius, investicijos i aukštaji moksla, nustatymas kaip greitai viešasis sektorius aptarnauja versla, moksliniu tyrimo istaigu, akademinio ir verslo sektoriu tarpusavio bendradarbiavimas, išlaidos infrastruktūrai gerinti, kuriamos ir diegiamos inovacijos.

Straipsnyje pateiktas naujas požiūris i inovaciju raiškos šalyje nustatymo galimybes. Siekiant išgryninti dažniausiai pasikartojančias kriteriju grupes, susisteminti egzistuojantys inovacijų raiškos vertinimo indeksai. Galimybės suskirstytos į dvi specifines (kokybinių ir kiekybinių) kriterijų grupes. Kaip teorinio ir empirio tyrimo rezultatas, sudaryta ir pritaikyta Lietuvai kriteriju išklotinė inovaciju raiškai šalyje nustatyti. Pastebèta, kad inovaciju raiška Lietuvoje nustatoma tik pagal patentų registro bei eksporto statistikos duomenis. Pasaulyje taikomi indeksai netinkami, sudètingi taikyti dèl greitai besikeičiančios metodologijos bei tyrimu rezultatų taikymo problemiškumo. Empirinis tyrimas taip pat leido išgryninti šešias jautriausias kriteriju grupes ir taip patobulinti teorinę kriteriju išklotinę. Šias rodikliu grupes atspindi: mokesčiai, lengvatos patentams, paruošta teisinè bazè inovacinei veiklai, R\&D plètra, aukštaji išsilavinimą turinčių asmenų skaičius, darbuotojų skaičius pagal išsilavinimą, rizikos kapitalas (proc. nuo BVP), universitetų, tyrimo centrų bendradarbiavimas su verslu, mokesčiu sistema inovatyvioms įmonèms, vyriausybès politikos efektyvumas, inovacijų centrų, mokslo verslo parku efektyvumas, aukštojo mokslo kokybė, švietimas ir ugdymas apie antrepreneriškumą, inovatyvių patentu, produktu, paslaugu skaičius, eksportas, politinė parama inovacijoms, tyrimo centrų veiklos sritys, išlaidos darbuotojų kvalifikacijai kelti, ,purpurinių“ imonių skaičius bei jų veiklos kryptys, inovatyvaus verslo savybès, infliacija, nedarbo lygis, verslo likvidumo laikas, išlaidų dalis naujoms informacinèms technologijoms, išlaidos aukštajam mokslui (nuo BVP), inovacinės veiklos igyvendinimas ir atsipirkimas, BVP, infrastruktūros aplinka šalyje, socialinè gerovė.

Straipsnyje taip pat pasiūlyti išklotinès naudojimo metodai bei sritys (susistemintas kriterijų išklotinès taikymo algoritmas). Teigiama, kad kriteriju išklotinès panaudojimo metodai tiesiogiai priklauso nuo inovaciju raiškos valstybès lygmeniu tyrimo tikslo (šis gali būti konstatuojamasis arba analitinis). Priklausomai tuo tikslo pobūdžio galima rinktis koncentruotą (mažai kriteriju apimantị) arba išplèstini (daug kriteriju apimantị) tyrimo metoda. Pirmasis leis pateikti kiekybines išvadas, o antrasis - ir kiekybines, ir kokybines. Kriteriju išklotinès panaudojimo sritys - valstybès makroekonomika. Inovacijų raiška taip pat gali būti nustatyta ir atskiruose ekonomikos sektoriuose.

Raktažodžiai: inovaciju raiška; Nacionaliné inovaciju sistema (NIS); kriteriju išklotine inovaciju raiškai nustatyti.

The article has been reviewed.

Received in October, 2011; accepted in April, 2012. 